\title{
The Polish political scene as seen from a small town market
}

\author{
Anna Malewska-Szalygin (University of Warsaw)
}

This article presents the results of field research carried out in the spring of 2004 in the town of Nowy Targ (Podhale region, Poland), by the Institute of Ethnology and Cultural Anthropology at the University of Warsaw. The research was based on open-ended interviews - or rather long conversations - with the vendors in the market square, enabling us to observe the political scene from a particular point of view. They interviews brought out the perception of the authorities 'from below'. This perspective uncovered many aspects of politics that are normally hidden behind the legislative language of the Constitution or even behind the informative language of the mass media.

\section{Introduction}

Since 1999 the Institute of Ethnology and Culture Anthropology at the University of Warsaw has been doing research on local discourses about politics. Fieldwork was carried out in the villages of Nowy Targ district in the Podhale region of southern Poland, from 1999-2000, and in the market square in Nowy Targ in 2001 and 2004. ${ }^{1}$ I participated in this research, mainly using an anthropological method based on long conversations, in accordance with the research directions. This method was meant to explore the perception of the authorities 'from below', allowing us to unmask the 'rhetoric of the ideal types of a modern nation-state' by comparing this with 'practices, which are to be masked by this rhetoric' (Herzfeld 2001:119). The anthropological method brought out a particular perspective; a position from which people watch what subjects exercising authority are really doing, and how the authority is actually exercised. We also used discourse analysis as a valuable complement to this. As Michel Foucault reminds us, authority is established and exercised through discourse (Foucault 2003). Representations (meanings of authority) form, change, and last in public debates (Geertz 2001:76). Therefore, by focusing on language, talk, terms and formulations used, we sought to scrutinise politics through the informants' eyes.

\footnotetext{
${ }^{1}$ Podhale is a particularly mountainous region in the south of Poland, including the stretch of the Tatra Mountains. It is worth stressing that inhabitants of this region (in Polish: Górale) still exhibit various signs of devotion to 'traditional' ways of life. They are famous for what is taken to be peculiar local knowledge and a disposition to gamble; Górale are said to be wise, smart and doughty people and are sometimes called 'folk philosophers'. Many of them have emigrated in order to earn a better living in the United States and, more seldom, in Western European countries.
} 


\title{
Politics as seen by Weber
}

First of all I should define the term 'politics'. In my opinion, we should recall Max Weber's definition. In his lecture Politik als Beruf (Politics as a Vocation), given in 1919 in Munich, he asked: 'What do we understand by politics?' and answered:

\begin{abstract}
'The concept is extremely broad and comprises any kind of independent leadership in action... Tonight, our reflections are, of course, not based upon such a broad concept. We wish to understand by politics only the leadership, or the influencing of the leadership, of a political association, hence today, of a state... a state is a human community that (successfully) claims the monopoly of the legitimate use of physical force. Hence, "politics" for us means striving to share power or striving to influence the distribution of power, either among states or among groups within a state. He who is active in politics strives for power either as a means in serving other aims, ideal or egoistic, or as "power for power's sake".' (Weber 1994:309-310, original emphasis)
\end{abstract}

This description shows how unclear the difference between 'politics' and 'authority' is. Politics can be understood broadly, as an administrative activity, or narrowly, as bringing pressure to bear on people in order to achieve an aim.

Weber concentrates on the politicians, people active in politics 'as work and vocation'. Describing the ideal model, Weber mentions three pre-eminent qualities that are decisive for the politician: passion, a feeling of responsibility, and a sense of proportion (ibid:330-331). He understands 'passion' to be devotion to a cause, an engagement controlled by responsibility and by a certain distance to reality, which enables a politician to let realities work upon him or her with inner concentration and calmness. Weber writes that politics is a strong and slow process of boring into hard boards, which takes both passion and perspective (ibid:369). Self-conceit and admiration of power are therefore the worst weaknesses of a politician.

In general the author of Politics as a Vocation does not consider politics to be a purely ethical activity. Rather, he thinks that the greatest value of politics is efficiency (it should, however, be led fairly). Weber distinguishes between the ethics of absolute ends (which he sees as based on the Christian Gospel) and the ethics of responsibility. Those who subscribe to the latter should, according to Weber, take common human weaknesses into consideration when pursuing their aims. The aims themselves should be 'good', whereas the means leading to them may not always be so. Weber writes:

'The genius - or demon - of politics lives in the inner tension with the god of love, as even with the Christian God as manifested in the institution of the church, a tension that may erupt at any moment into irresolvable conflict.' (ibid:366)

And, just before this passage:
'Anyone wishing to practice politics of any kind, and especially anyone who wishes to make a profession of politics, has to be conscious of these ethical paradoxes and of his responsibility for what may become of himself under pressure from them. He is becoming involved, I repeat, with the diabolical powers that lurk in all violence.' (ibid:365)

Politics, for Weber, is an activity related to a factor of violence, and by virtue of this may be morally dangerous, even demonic (from a cosmological point of view). Now it is time to bring these theoretical deliberations to bear on the images of politicians drawn up by inhabitants of the Podhale region. 


\section{Politics as seen from a market square}

The interviews that we conducted in a market square in March 2004 were in some ways peculiar and differed widely from those conducted in village houses. There are no very old or very young people selling in the market, and there are no unemployed or very poor people. The vendors are entrepreneurs: they pay taxes for running businesses and for employing workers. The main subject of our conversations therefore turned out to be the problems of running a business in a country which disturbs this activity.

When we mentioned the government's slogan of giving 'the green light to encouraging entrepreneurs' the vendors burst out laughing. They pointed out to us the permanent increase in taxes, such as the so-called ZUS (for the Social Insurance Institution, Zakład Ubezpieczeń Społecznych) and VAT (value added tax), which make small business enterprises less and less profitable. The vendors defined these national fiscal encumbrances in their own words, referring to zusy francowate ('damn ZUSes') or zusy-śmusy ('ZUSy-schmoozy'). As business entrepreneurs they were well informed about numbers, and they complained about the fiscal system mentioning actual amounts:

'Now when a private [self-employed] makes [business] he must pay more than 600 zloty for ZUS. And they [the authorities] are gonna increase ZUS to $120 \%$ of national average wage?! The average wage is about 1,080 zloty, so ZUS is to be 1,300 zloty per month. Let them earn so much on the market, madam, pay the tax and support the family. No way!'

The national average wage itself also made people irritated. 'Who earns so much?' our interlocutors asked, and they would observe that ordinary people 'make 1,000 zloty and think they've done well'. The vendors compared the situation to the one they experienced in the USA. They said that running a business over there did not require so many formalities. First of all a business person in the USA was not encumbered with such high fiscal charges:

\footnotetext{
'At ours, in Poland, it is different than in America-all is VATed, and how! It's impossible! Everybody runs away from Poland! Though there's enough work here! If only the government didn't disturb people! Away with this ballast!'
}

There was much exasperation and feeling of injustice in the responses of our interlocutors. They also asked why the largest part of the national budget was fed by people with the lowest incomes. Why, they demanded, did bigger enterprises, like the branches of French supermarkets in Poland, pay taxes in their home country, 'while the Polish economy takes taxes from us, the poorest?'

When politicians spend money and bring nothing to the budget, however, our interlocutors were made even angrier than over the injustices of the tax policy. Politicians get money without fighting on the market or working physically; in short, as our interlocutors commented: 'they don't work'. From time to time the public gets to know that they embezzle some of the public funds but take no responsibility. The inequality between ordinary citizens and politicians is made strongly visible when a small-scale business entrepreneur comes into conflict with the revenue authorities.

'I shake with fear to pay this ZUS to a penny, otherwise they... me, while the politicians steal millions and that is to be OK, no one prosecutes 
them... If I had stolen 1,000 zloty, they wouldn't have let me. And somebody steals millions and remains untouchable!'

Another group of people that we met in the market were the farmers who came there to sell their goods. Most of the farmers have a small piece of land divided into oat and rye fields, and often a meadow to feed their cows and sheep. People have never been able to make a livelihood from agriculture alone in the mountains. That is why the mountaineers have always searched for different ways of attaining additional incomes. In the communist period this could be a monthly salary from the shoe factory 'Podhale', or another state enterprise, or sometimes work in the USA. Work abroad has become a more common source of additional income recently.

When we asked some 50-year-old men selling grain about their sources of income, we received this answer from one of them:

'We're Yankees, Italians, Germans and Austrians. Now every one who works, works abroad. There's little young people left here. Everybody has run away. I'm alone, though there were nine of us, brothers and sisters.'

His own choice not to emigrate does not mean he is not hobo (a traveling worker): 'I get back for the winter to take care of the sheep,' he explained. 'In the summer - put the sheep on a pasture and-I go to work.' When we asked why he didn't sell his unprofitable farm, he answered: 'It's my heritage,' and then added: 'It's a kind of hobby. I mow so it doesn't grow over, like in Bieszczady.' It is because of seasonal work migration that the economic situation in Podhale is not too dire. When asked if it was impossible to earn money working in Poland the men answered in a sarcastic way: 'One of the politicians from the peasant party started with a farm of five hectares, and after two years of functioning has gained a farm of 200 hectares, so it is possible, but not honest.'

Having briefly described our interlocutors, I will now turn to one of the themes of our market debates, namely politics defined in Weberian terms as the leadership of a state. According to our interlocutors, those who rule a state, in the same way as those who manage a household, must be competent and fair. Polish authorities, our informants said, were not competent enough. But the biggest problem was that it was not sufficiently fair: 'It's impossible, with all these thieves and swindlers!' A 50-year-old man with elementary education was sure that, 'The mafia rules everything. Favoritism is all around. It doesn't matter, they are replacing one another-but it is still the same squad. Only the names are changing, but everything is tied.' This statement contains some universal claims characteristic of the local knowledge of politics. The domain of authority is not a transparent domain where a person who is given public trust will work for his or her voters. Instead, authority is a dark zone, where everything is wellconnected: politics, economy and the underworld. Politicians, business people and criminals are tied together in unclear deals. The result of these connections is a corruption of the state and a selling out of the national property. As one informant put it: 'They will soon steal all the country away. All will be sold out. And there will be nothing left. Government, court, police, doctors, they're all corrupt... We only know about one out of every ten of their scams!'

Indeed the strongest emotions of our interlocutors, during all the five years of our research in Podhale, were triggered by the topic of the selling out of national property. They raised their voices, they started to use rude words. It was clear just how personally this issue was taken, though at the beginning of the conversation they 
would claim that they were not interested in politics. As one said:

'It's all fuckin' theft. They sold out so much of the national property. They have stolen so much. They fuck it all. Careerists... We've been working, toiling for 50 years, all of us. And today it's all sold out. For fuckin' pennies.'

Theft and a lack of thriftiness were the main accusations against the authorities. Thus any enlargement of the administration also made our interlocutors irritated:

'When they took power there were 260,000 clerks. Now there are 480,000 of them. 480,000! And this cock sucker who makes reforms, this vice minister Hausner, he said there would be a reduction in the administration, and? Sixty less of 480,000. I thought I had misunderstood. Maybe 60,000 ? But no! It was just 60 . Is that the reform he planned?!'

Our task was also to find out whether the local business entrepreneurs thought that a positive change in the way that the state is run would be possible. When asked what could be done in Poland, our interlocutors said change would come through change in the law. For them the law was intentionally unclear, inexact, and made not for common but for individual benefit. Our interlocutors described this problem in simple words: 'The MPs make laws for themselves, to avoid punishment.' For now both a transparent law and punishment is needed: 'There must be a punishment. Then the one who governs would be responsible. And when he governs unfairly, then - to the gallows! And all these who steal should be hung... Hung by their balls.'

When asked about public ways of overhauling the state many people told us they would not vote in 2005 , because there was nobody to vote for and all the candidates 'are sunk in this mud.' In 2000 and 2001 we heard similar voices, but in 2004 they seemed to be more common: 'I don't care. I know they are all thieves and I don't vote.' Most of the interlocutors were not able to react calmly: 'We don't trust any government... We won't change anything. I think it will drive us to civil war, like in Argentina where people rioted. One brother will kill another!'

As we were also trying to find out whether there were any aspects of political life that were perceived positively, we asked about local policy. The answers didn't bring the expected results, as the picture of the local administration was not much different from that of the central administration: 'Our chief [of the commune] is in jail. What an honest guy he was! He's there for a bribe.' Further we were told that bribery, favoritism and nepotism are blossoming in the commune. Our optimistic thesis that the local administration might be perceived as closer to the people and more ethical was not confirmed.

The answers we were given in March 2004 concerning whom to vote for differed from the answers we were given before the elections of 2001. The main difference was disappointment in the SLD (Democratic Left Alliance) government, which had enjoyed a high degree of trust in 2001. In March 2004 it was clear that the SLD government of Leszek Miller had not fulfilled expectations. This primarily meant that it had not made the economic situation of Poland better and had not been more upstanding than the previous government, which was formed by the political powers relating to Solidarnosc and which had brought much disappointment. The result was that plenty of people were now dissatisfied. 'They escaped the reds [communists], because their promises failed. Miller has done nothing to make things better. But the farmers see what is going on-recess deepens.' 
Bearing in mind the constantly repeated opinion that only an authority represented by a strong and powerful person would make the situation in Poland better, we asked about the president, Aleksander Kwaśniewski, as an office bearer and as a person. The locals, in their usual manner, answered us jokingly and sarcastically: 'Listen, Kwasniewski does what he does best-he does nothing. He doesn't disturb anybody. He's just sitting on his post and taking money for that. He nods to everybody and doesn't expose himself to anybody's displeasure.' Deliberating on possible candidates for the next elections, our interlocutors mentioned the president's wife, Jolanta Kwasniewska, and joked that she would probably not disturb anyone, just like her husband, but that unlike him she would at least do something good for ill children. The sarcasm of these jokes is more understandable if one knows the local Podhale opinion on how a president should act. Most of our interlocutors were supporters of a strong administration concentrated in one post, as in the USA model, where the president's powers are wide and have an influence on both domestic and foreign policy. In the face of these expectations, the Polish president, whose powers are limited to representing the state and sometimes to making use of his right to vetoing acts, doesn't look too powerful: 'As things are as they are in Poland, there's no need to have such a post.' I should also note, however, that a few people did express the opinion that Aleksander Kwasniewski implemented his representative tasks abroad very well.

\section{Conclusion: Weber in Podhale}

Listening to the market debates one can conclude that the Podhale locals would agree with Weber's thesis that politics is a strong and slow process of boring into hard boards. The problem, as the market vendors see it, is that very few politicians are prepared to take on this hard work. Most of the politicians are seen as having an interest in using policy for their private benefit, instead of working for the common good. Weber says that politics is morally dangerous by nature. Our interlocutors, observing the Polish political scene from below, would agree. But they would not agree that this is an ideal state. Their opinions somehow also manage to bring out that they still believe in a politics that is ethical, upstanding, and considered a duty.

\section{References}

Foucault, M. 2003. Society Must Be Defended: Lectures at the College de France 1976-77. Translated by D. Macey. New York: Picador.

Geertz, C. 2001. Available Light: Anthropological Reflections on Philosophical Topics. Princeton: Princeton University Press.

Herzfeld, M. 2001. Theoretical Practice in Culture and Society. Oxford: Blackwell.

Weber, M. 1994. The profession and vocation of politics. In Max Weber: Political Writings (Cambridge Texts in the History of Political Thought) (ed.) P. Lassman, 309-369. Translated by R. Speirs. Cambridge: Cambridge University Press. 


\section{About the author}

Anna Malewska-Szalygin has a PhD and works as a tutor in the Institute of Ethnology and Culture Anthropology of the University of Warsaw. Her anthropological interests concentrate on the village inhabitants' common knowledge. Her first research project explored the common view of the past in the Roztocze region (East-South of Poland) from 1985-86. Her next research project focused on the local opinions about local authorities in the Mazury region (North-East of Poland) and was carried out from 1993-96. The subject of her current research in Podhale is the village discourse on politics. She can be contacted at anmalsz@,wp.pl 